\title{
SIFAT FISIKOKIMIA DAN SENSORIS BERAS ANALOG JAGUNG DENGAN PENAMBAHAN TEPUNG KEDELAI
}

\section{[Physicochemical and Sensory Characteristics of Corn-Based Rice Analog with Soybean Flour Addition]}

\author{
Tyas Hermala Anindita"), Feri Kusnandar ${ }^{2) \star}$, dan Slamet Budijanto ${ }^{2)}$ \\ 1) Program Studi IImu Pangan, Sekolah Pascasarjana, Institut Pertanian Bogor, Bogor \\ 2) Departemen Ilmu dan Teknologi Pangan, Fakultas Teknologi Pertanian, Institut Pertanian Bogor, Bogor
}

Diterima 10 Juli 2019 / Disetujui 7 Januari 2020

\begin{abstract}
Rice analogs are rice-like products processed from various non-rice carbohydrate sources, such as corn flour. A high-protein rice analog can be produced with the addition of soybean into the formula of corn-based rice analog. This research aimed to evaluate a high-protein rice analogs made with the addition of soybeans (Grobogan or Detam-1 variety) in terms of their chemical composition, water holding capacity, texture and sensory qualities. The rice analogs were produced from corn flour, soybean flour, sagoo starch, glycerol monostearate (GMS) and water using hot-extrusion methods. The percentage of Grobogan or Detam-1 soybean flour added varied, i.e. 10, 15, 20, and 25\%. The addition of soybean flour of Grobogan variety increased the protein content of the rice analog. A high-protein rice analog can be obtained by adding $20 \%$ Grobogan soybean flour or $15 \%$ Detam-1 soybean flour. The fat and dietary fiber content of rice analog also increased, while the carbohydrate content decreased. The hardness and cohesiveness of the rice analog decreased as the amount of soybean flour addition increased. However, panelists did not detect any changes up to $25 \%$ of soybean flour addition. The water holding capacity of the rice analog also decreased as the amount of soybean flour increased. The panelists detected the changes in water holding capacity starting from $20 \%$ soybean flour addition.
\end{abstract}

Keywords: analog rice, corn flour, plant-based protein, soybean flour

\begin{abstract}
ABSTRAK
Beras analog adalah suatu produk berbentuk bulir beras yang dapat diolah dari berbagai sumber karbohidrat selain beras, di antaranya jagung. Beras analog tinggi protein dapat dibuat dengan menam bahkan kacang kedelai ke dalam fomulasi beras analog jagung. Penelitian ini bertujuan untuk mengevaluasi beras analog tinggi protein sebagai pengaruh penambahan kacang kedelai (varietas Grobogan atau Detam-1), yaitu komposisi kimia, daya ikat air, tekstur serta karakteristik sensori beras analog yang dihasilkan. Beras analog dibuat dari bahan komposit yang mengandung tepung jagung, tepung kedelai, pati sagu, dan gliserol monostearat (GMS) dan air dengan metode ekstrusi panas. Perlakuan yang diberikan adalah persentase tepung kedelai variteas Grobogan atau Detam - 1 di dalam beras analog, yaitu 10, 15, 20, dan 25\%. Penambahan tepung kedelai varietas Grobogan atau Detam-1 sebanyak 10-25\% meningkatkan kadar protein dari beras analog. Beras analog tinggi protein berhasil dibuat dengan $20 \%$ tepung kedelai Grobogan atau 15\% tepung kedelai Detam-1. Selain itu, kadar lemak dan serat pangan dari beras analog juga meningkat, serta kadar karbohidratnya menurun. Peningkatan jumlah tepung kedelai yang ditambahkan menurunkan kekerasan (hardness) dan kepaduan (cohesiveness) dari beras analog yang dihasilkan. Namun, panelis tidak mendeteksi perubahan tersebut hingga penambahan tepung kedelai $25 \%$. Daya ikat air juga menurun seiring bertambahnya tepung kedelai. Panelis mendeteksi terjadinya perubahan tersebut pada penambahan tepung kedelai $20 \%$.
\end{abstract}

Kata kunci: beras analog, protein nabati, tepung jagung, tepung kedelai

*Penulis Korespondensi: E-mail: fkusnandar@apps.ipb.ac.id 


\section{PENDAHULUAN}

Beras analog adalah suatu produk berbentuk bulir beras yang dapat diolah dari berbagai sumber karbohidrat selain padi. Pengembangan beras analog dari berbagai sumber karbohidrat non-beras telah banyak dilaporkan, di antaranya dari jagung putih (Noviasari et al., 2013), sorgum (Budijanto dan Yuliyanti, 2012), ubi kelapa putih (Adicandra dan Estiasih, 2016), umbi garut (Caesarina dan Estiasih, 2016), dan pisang (Yudanti et al., 2015). Beras analog juga dapat dibuat dari bahan baku campuran, seperti campuran dari jagung kuning, bekatul, sagu dan kedelai (Kurniawati et al., 2016), dan campuran tepung sagu dan kacang merah (Wahjuningsih et al., 2016). Penggunaan bahan baku campuran ini bertujuan untuk memperbaiki nilai gizi beras analog yang dihasilkan. Penggunaan bahan lainnya ditujukan untuk memperbaiki mutu fisik dan sensori beras analog, seperti penambahan tepung singkong termodifikasi (modified cassava flour), maizena, hidrokoloid dan ampas tahu (Yuwono dan Zulfiah, 2015).

Salah satu pengembangan lain dari beras analog untuk meningkatkan nilai tambahnya adalah sebagai pangan berprotein tinggi dengan menambahkan pangan sumber protein. Pangan tinggi/kaya protein harus mengandung tidak kurang dari 35\% Acuan Level Gizi (ALG) per $100 \mathrm{~g}$ untuk produk padat (BPOM, 2016). Beras analog ini dapat bermanfaat untuk meningkatkan as upan protein bagi konsumen yang memerlukannya. Kecukupan protein dalam diet seseorang penting untuk mempertahankan fungsi normal tubuh, di antaranya untuk pertumbuhan dan pemeliharaan jaringan otot (Wolfe, 2012). Di samping dapat meningkatkan kadar protein dalam beras analog, bahan yang ditambahkan juga diharapkan dapat meningkatkan karakteristik fisik beras analog. Penelitian terdahulu menunjukkan bahwa penambahan bahan berprotein tinggi dapat meningkatkan daya ikat air pada tepung komposit terigu dan kedelai (Traynham, 2007), tekstur muffin bebas gluten (Shevkani dan Singh, 2014), dan kekuatan gel tepung komposit jagung dan protein kedelai (Li et al., 2007). Julianti et al. (2015) juga melaporkan bahwa penambahan ubi, pati jagung, kedelai dan xanthan gum dapat menghasilkan daya ikat air yang lebih tinggi apabila ditambahkan pada tepung terigu.

$\mathrm{Di}$ antara teknologi pembuatan beras analog yang dikembangkan adalah teknologi ekstrusi yang dapat menghasilkan bulir yang menyerupai beras asli (Mishra et al., 2012). Pembuatan beras analog dengan teknologi ekstrusi mencakup tahapan formulasi bahan, pencampuran, ekstrusi, dan pengeringan. Dalam tahap formulasi, tepung dari berbagai sumber ditambah dengan bahan lain, yaitu gliserol monostearat yang berfungsi sebagai bahan pengemulsi. GMS akan berikatan dengan amilosa dan membentuk sebuah jaringan (Putseys et al., 2010). Bahan-bahan tersebut dicampur dengan penambahan air hingga merata, lalu diekstrusi pada suhu $85-100^{\circ} \mathrm{C}$. Suhu ekstrusi dapat berbeda antar proses yang dipengaruhi oleh bahan baku yang digunakan. Herawati et al. (2013) menyatakan bahwa suhu ekstruder $95^{\circ} \mathrm{C}$ menghasilkan bentuk butiran granula yang bagus menyerupai produk beras. Dalam proses ekstrusi, adonan yang melewati lubang (die) mengalami proses gelatinisasi dan pembentukkan (Mishra et al., 2012). Ekstrudat beras analog yang dihasilkan selanjutnya dikeringkan dalam oven dengan suhu $70^{\circ} \mathrm{C}$ sekitar 3 jam hingga kadar air kurang dari $14 \%$.

Bahan pangan sumber protein yang dapat dimanfaatkan untuk pembuatan beras analog tinggi protein adalah kacang kedelai. Di antara varietas kacang kedelai yang potensial untuk dimanfaatkan adalah kedelai lokal varietas Grobogan dan Detam 1. Balitkabi (2016) menyatakan bahwa kedua varietas kacang kedelai ini mengandung protein yang cukup ting gi, yaitu $43.90 \%$ (varietas Grobogan) dan $45.40 \%$ (varietas Detam-1). Kandungan protein dari kedelai varietas Grobogan dan Detam-1 lebih tinggi dari kandungan protein beberapa kedelai lainnya, seperti kedelai varietas Wilis, Mallika, Cikuray, dan bahkan kedelai impor (Nurrahman, 2015; Ginting et al., 2015; Hidayat et al., 2010). Selain mengandung protein tinggi, kedelai hitam varietas Detam -1 mengandung antosianin dan total senyawa fenolik yang cukup tinggi (Triandita et al., 2016). Kedelai yang digunakan dalam penelitian ini adalah kedelai utuh yang diolah menjadi tepung dengan pengolahan yang minimal untuk menekan biaya produksi sehingga dapat menghasilkan produk beras analog dengan harga yang terjangkau. Selain itu, kedelai utuh juga memiliki berbagai komponen yang bermanfaat bagi kesehatan, diantaranya serat pangan, vitamin, mineral, serta lemak tidak jenuh seperti asam linolenat dan linoleat (Krisnawati, 2017).

Tujuan dari penelitian ini adalah untuk mengembangkan beras analog tinggi protein dengan bahan baku jagung yang ditambahkan tepung kedelai dan mengevaluasi karakteristik fisikokimia dan sensori dari produk yang dihasilkan. Kacang kedelai yang digunakan adalah dari varietas Grobogan dan Detam-1 dengan penambahan kedelai masing-masing $0,10,15,20$, dan $25 \%$. Hal ini dilakukan untuk menentukan seberapa banyak tepung kedelai dapat ditambahkan untuk mendapatkan beras analog tinggi protein dengan meminimalkan perubahan fisik yang dapat dirasakan secara sensoris oleh konsumen. 


\section{BAHAN DAN METODE}

\section{Bahan}

Bahan baku jagung dalam penelitian ini diperoleh dari Kediri Corn Mill. Kacang kedelai yang digunakan terdiri dari varietas Grobogan (dari Balai Besar Penelitian Bioteknologi dan Sumberdaya Genetik Pertanian, Bogor) dan varietas Detam-1 (dari Balai Penelitian Tanaman Aneka Kacang dan Umbi, Malang) yang diperoleh pada bulan Maret 2017. Bahan-bahan lainnya yang digunakan dalam proses pembuatan beras analog adalah pati sagu dan glycerol monostearate (GMS) yang diperoleh dari suplier lokal.

\section{Pembuatan tepung kedelai (Otegbayo et al., 2018 dengan modifikasi)}

Kedelai dicuci dengan air kemudian direbus selama 10 menit pada suhu $100^{\circ} \mathrm{C}$. Kedelai kemudian ditiriskan, lalu dikeringkan dalam oven pada suhu $70^{\circ} \mathrm{C}$ selama 5 jam. Setelah kering, kedelai dipecah dengan menggunakan hammer mill dan setelah itu ditepungkan dengan menggunakan disc mill, lalu diayak untuk menghasilkan tepung kedelai yang memiliki ukuran 80 mesh.

\section{Pembuatan beras analog (Budijanto dan Yulianti 2012, dengan modifikasi)}

Bahan-bahan yang digunakan, seperti tepung jagung, tepung kedelai (Grobogan atau Detam-1), GMS, pati sagu, dan air, diformulasi dengan jumlah yang ditambahkan masing-masing sebagaimana disajikan pada Tabel 1. Air ditambahkan sebanyak $50 \%$ dari bobot tepung. Bahan-bahan lalu dicampur hingga merata selama 10 menit dengan menggunakan mixer. Adonan yang sudah dicampur lalu diekstrusi dengan menggunakan ekstruder ulir ganda (Berto Industries BEX-DS-2256) dengan pengaturan kecepatan ulir $100 \mathrm{rpm}$, kecepatan ulir feed $15 \mathrm{rpm}$ dan suhu $95^{\circ} \mathrm{C}$. Bulir beras analog yang dihasilkan kemudian dikeringkan dalam oven pada suhu $70^{\circ} \mathrm{C}$ selama 3 jam.

Tabel 1. Formula beras analog jagung dengan penambahan tepung kedelai varietas Grobogan/Detam-1

\begin{tabular}{lccccc}
\hline \multirow{2}{*}{ Bahan } & \multicolumn{5}{c}{ Perlakuan } \\
\cline { 2 - 6 } & 1 & 2 & 3 & 4 & 5 \\
\hline Tepung Jagung (\%) & 88 & 78 & 73 & 68 & 63 \\
Tepung kedelai (\%) & 0 & 10 & 15 & 20 & 25 \\
GMS (\%) & 2 & 2 & 2 & 2 & 2 \\
Pati sagu (\%) & 10 & 10 & 10 & 10 & 10 \\
\hline
\end{tabular}

\section{Analisis komposisi kimia}

Analisis kimia yang dilakukan meliputi analisis proksimat, yaitu kadar air (menggunakan oven), kadar abu (menggunakan tanur), kadar protein (metode kjeldahl), kadar lemak (metode soxhlet) dengan mengacu pada metode AOAC (2005), analisis kadar karbohidrat, dan analisis serat pangan. Kadar karbohidrat dihitung by difference. Analisis serat pangan mengacu pada McCleary et al. (2013). Data proksimat dinyatakan dalam persen basis kering (\%bk), kecuali kadar air.

\section{Pengukuran daya ikat air (Lee et al., 2012)}

Sampel berbentuk tepung ditimbang sebanyak $1 \mathrm{~g}$ dan dimasukkan ke dalam tabung sentrifus yang sudah ditimbang terlebih dahulu. Sebanyak $10 \mathrm{~mL}$ akuades lalu dimasukkan ke dalam tabung sentrifus, dikocok selama 10 menit dan disentrifusi pada 3000 rpm selama 30 menit. Supernatan kemudian dibuang dan berat tabung berisi sedimen ditimbang. Daya ikat air dihitung sebagai persentase dari berat air yang terdapat dalam sampel setelah dekantasi dibandingkan berat sampel.

\section{Pengukuran tekstur (Modifikasi dari Li et al., 2016)}

Tekstur diukur dengan Texture Analyzer (TAXT2) dengan menggunakan probe silinder $35 \mathrm{~mm}$. Mode yang dipilih adalah Texture Profile Analysis (TPA) sehingga sampel ditekan sebanyak dua kali. Pengaturan alat dilakukan pada kondisi yang sama untuk semua sampel, yaitu: pre-test speed $2.0 \mathrm{~mm} /$ detik, test speed $2.0 \mathrm{~mm} /$ detik, post-test speed 2.0 $\mathrm{mm} /$ detik, dan test distance $90 \%$. Sampel yang dianalisis adalah nasi analog, dengan metode pemasakan menggunakan penanak nasi. Air yang telah dididihkan kemudian dicampurkan dengan beras (perbandingan 1:1), lalu pemasakan dilanjutkan selama 3 menit. Setiap sampel dianalisis sebanyak 5 kali ulangan. Kurva yang diperoleh dianalisis untuk menentukan nilai kekerasan dan kepaduan dari sampel nasi. Kekerasan (hardness) adalah kekuatan maksimal pada penekanan pertama dan dinyatakan dalam gram $(\mathrm{g})$, sedangkan kepaduan (cohesiveness) dihitung sebagai rasio antara area di bawah kurva kompresi kedua dengan area di bawah kurva kompresi pertama (tanpa satuan).

\section{Pengujian sensori (Sitakalin dan Meullenet, 2000)}

Uji sensori sampel dilakukan dengan metode quantitative descriptive analysis (QDA). Sampel yang dinilai adalah beras analog yang telah dimasak. Sampel beras dimasak menggunakan penanak nasi (perbandingan air dan beras: 1:1 (v/v)). Air dididihkan terlebih dahulu, kemudian dicampurkan dengan beras dan pemasakan dilanjutkan selama 35 menit. Penilaian sampel dilakukan oleh 13 orang panelis yang diseleksi dan dilatih. Setiap panelis diberi sampel nasi sebanyak satu sendok makan. Penilaian oleh panelis dilakukan dengan memberikan tanda pada garis yang tidak terstruktur sepanjang $15 \mathrm{~cm}$. Atribut tekstur nasi yang diuji meliputi 
kekerasan (hardness), kepaduan massa (cohesiveness), kelengketan (stickiness), dan kelembapan (moistness). Untuk mempermudah penilaian, panelis disediakan juga sampel makanan referensi untuk tiap atribut tekstur dengan nilai yang sudah ditentukan. Definisi dari tiap atribut dan referensi sampel makanan untuk atribut kelengketan, kekerasan, dan kepaduan massa diperoleh berdasarkan Sitakalin dan Meullenet (2000), sedangkan definisi dan referensi untuk atribut kelembapan diperoleh berdasarkan Kwak et al. (2015) dan Huang et al. (2014). Definisi, cara pengujian dan sampel makanan referensi beserta skornya disajikan pada Tabel 2 .

\section{Analisis data}

Penelitian ini dilakukan dengan menggunakan rancangan acak kelompok (RAK) sebanyak dua kali ulangan. Desain penelitian terdiri dari satu faktor (konsentrasi kedelai) dan lima taraf perlakuan (konsentrasi kedelai $0,10,15,20$, dan 25\%) dengan jenis kedelai sebagai kelompoknya. Analisis statistik dilakukan menggunakan metode analisis ragam (ANOVA) dengan taraf signifikansi 5\%, kemudian dilanjutkan dengan uji lanjut menggunakan uji selang berganda Duncan. Nilai signifikansi ditentukan berdasarkan taraf nyata $5 \%$.

\section{HASIL DAN PEMBAHASAN}

\section{Komposisi kimia}

Hasil analisis proksimat pada Tabel 3 menunjukkan bahwa jagung mengandung protein, lemak dan karbohidrat secara berturut-turut $6,63 \pm 0,02$; $0,87 \pm 0,00$; dan $79,28 \pm 0,03 \%$. Kedelai varietas Grobogan mengandung protein dan lemak yang tinggi $(34,47 \pm 0,03$ dan $19,76 \pm 0,02 \%)$, dengan karbohidrat lebih rendah $(33,35 \pm 0,06 \%)$. Kedelai hitam varietas
Detam-1 mengandung protein lebih tinggi dibandingkan kedelai varietas Grobogan $(39,70 \pm 0,02 \%)$, namun mengandung lemak dan karbohidrat lebih rendah $(16,88 \pm 0,02$ dan $28,82 \pm 0,02 \%)$. Kadar protein kedelai yang diperoleh dalam penelitian ini lebih rendah daripada kadar protein kedelai varietas Grobogan dan Detam-1 yang dilaporkan oleh Balitkabi (2015), yaitu 43,90\% (kedelai Grobogan) dan $45,40 \%$ (kedelai Detam-1). Perbedaan kadar protein ini dapat terjadi karena perbedaan kondisi lingkungan tumbuh dari kedelai tersebut (Krisnawati, 2017).

Penambahan kedelai ke dalam formulasi beras analog meningkatkan kadar protein secara nyata $(P<0,05)$ (Tabel 4$)$. Beras analog tanpa penambahan tepung kedelai mengandung protein sebanyak $6,53 \pm 0,26 \%$, sedangkan yang diberi penambahan tepung kedelai Grobogan atau Detam-1 sebanyak

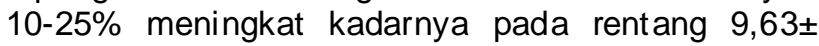
0,20-15,51 $\pm 0,54 \%$ (untuk tepung kedelai Grobogan) dan $10,94 \pm 0,43-17,45 \pm 0,50 \%$ (untuk tepung kedelai Detam-1). Kadar protein beras analog meningkat seiring dengan peningkatan jumlah tepung kedelai yang ditambahkan. Dengan kadar protein tersebut, maka beras analog yang dihasilkan dapat digunakan untuk konsumen yang memerlukan asupan protein cukup tinggi. Berdasarkan Peraturan Kepala Badan Pengawas Obat dan Makanan (BPOM) Nomor 13 Tahun 2016 tentang Pengawasan Klaim pada Label dan Iklan Pangan Olahan (BPOM, 2016) dan Peraturan Kepala BPOM tentang Acuan Label Gizi (BPOM, 2016), klaim beras analog tinggi protein dapat diberikan pada beras analog dengan penambahan kedelai varietas Grobogan 20\% dan kedelai varietas Detam-1 15\% dengan ukuran porsi $60 \mathrm{~g}$ beras sebanyak tiga kali sehari, dimana masingmasing berkontribusi terhadap asupan protein sebanyak 22,51 dan 21,27 g/hari.

Tabel 2. Definisi dan makanan referensi yang digunakan untuk untuk atribut sensori tekstur nasi dari beras analog jagung dengan penambahan tepung kedelai varietas Grobogan/kedelai Detam-1

\begin{tabular}{|c|c|c|c|c|}
\hline Atribut & Definisi & Cara Pengujian & Referensi & Skor \\
\hline $\begin{array}{l}\text { Kelengketan } \\
\text { pada bibir }\end{array}$ & $\begin{array}{l}\text { Derajat kelengketan sampel } \\
\text { pada bibir }\end{array}$ & Tekan sampel diantara bibir, & $\begin{array}{c}\text { Nougat } \\
\text { Pretzel kering }\end{array}$ & $\begin{array}{r}2,0 \\
100\end{array}$ \\
\hline Kekerasan & $\begin{array}{l}\text { Kekuatan yang dibutuhkan } \\
\text { untuk menekan sampel }\end{array}$ & $\begin{array}{l}\text { Tekan sampel satu kali dengan } \\
\text { geraham atau gigi depan }\end{array}$ & $\begin{array}{l}\text { Putih telur } \\
\text { Kacang tanah }\end{array}$ & $\begin{array}{l}2,5 \\
9,5\end{array}$ \\
\hline $\begin{array}{l}\text { Kepaduan } \\
\text { massa }\end{array}$ & $\begin{array}{l}\text { Derajat dimana sampel yang } \\
\text { dikunyah menyatu }\end{array}$ & $\begin{array}{l}\text { Kunyah sampel sebanyak } 3 \text { kali dan } \\
\text { evaluasi }\end{array}$ & $\begin{array}{l}\text { Wortel } \\
\text { Keju }\end{array}$ & $\begin{array}{l}2,0 \\
9,0\end{array}$ \\
\hline Kelembapan & $\begin{array}{l}\text { Persepsi kelembapan saat } \\
\text { sampel dikunyah }\end{array}$ & $\begin{array}{l}\text { Evaluasi kelembapan saat } \\
\text { mengunyah sampel nasi }\end{array}$ & $\begin{array}{l}\text { Bagelen } \\
\text { Apel }\end{array}$ & $\begin{array}{c}2,0 \\
10,0\end{array}$ \\
\hline
\end{tabular}

Keterangan:Sumber=Sitakalin dan Meullenet(2000); Kwak et al. (2015); Huang et al. (2014)

Tabel 3. Kandungan kimia jagung dan kedelai yang digunakan dalam pembuatan beras analog dengan penambahan tepung kedelai varietas Grobogan/kedelai Detam-1

\begin{tabular}{lccccc}
\hline \multicolumn{1}{c}{ Bahan baku } & Air (\% bb) & Abu (\% bk) & Protein (\% bk) & Lemak (\% bk) & Karbohidrat (\% bk) \\
\hline Jagung & $12,69 \pm 0,02$ & $0,53 \pm 0,01$ & $6,63 \pm 0,02$ & $0,87 \pm 0,00$ & $79,28 \pm 0,03$ \\
Kedelai grobogan & $7,86 \pm 0,00$ & $4,55 \pm 0,08$ & $34,47 \pm 0,03$ & $19,76 \pm 0,02$ \\
Kedelai detam-1 & $9,47 \pm 0,01$ & $5,13 \pm 0,01$ & $39,70 \pm 0,02$ & $16,88 \pm 0,02$ \\
\hline
\end{tabular}


Tabel 4. Komposisi kimia beras analog dengan penambahan tepung kedelai varietas Grobogan/Detam-1

\begin{tabular}{|c|c|c|c|c|c|c|}
\hline $\begin{array}{l}\text { Persentase } \\
\text { Kedelai (\%) }\end{array}$ & Air (\% bb) & Abu (\% bk) & Protein (\% bk) & Lemak (\% bk) & $\begin{array}{c}\text { Karbohidrat } \\
\text { (\% bk) }\end{array}$ & $\begin{array}{c}\text { Serat Pangan } \\
(\%)\end{array}$ \\
\hline \multicolumn{7}{|c|}{ Kedelai Grobogan } \\
\hline 0 & $6,80 \pm 1,14^{a}$ & $0,70 \pm 0,05^{a}$ & $6,53 \pm 0,26^{a}$ & $0,66 \pm 0,02^{a}$ & $92,11 \pm 0,30^{a}$ & $3,44 \pm 0,29^{a}$ \\
\hline 10 & $7,44 \pm 0,60^{a}$ & $1,12 \pm 0,07^{\mathrm{D}}$ & $9,63 \pm 0,20^{\circ}$ & $1,14 \pm 0,36^{\mathrm{a}}$ & $88,11 \pm 0,23^{\mathrm{D}}$ & $5,99 \pm 0,40^{\circ}$ \\
\hline 15 & $7,50 \pm 0,17^{\mathrm{a}}$ & $1,38 \pm 0,10^{\mathrm{D}}$ & $11,71 \pm 0,28^{c}$ & $2,41 \pm 0,58^{\mathrm{D}}$ & $84,50 \pm 0,40^{c}$ & $8,53 \pm 0,76^{c}$ \\
\hline 20 & $7,27 \pm 1,93^{a}$ & $1,67 \pm 0,07^{\mathrm{c}}$ & $13,49 \pm 0,02^{a}$ & $3,88 \pm 0,37^{\mathrm{C}}$ & $80,96 \pm 0,43^{a}$ & $9,12 \pm 0,84^{\mathrm{a}}$ \\
\hline 25 & $4,76 \pm 0,06^{\mathrm{D}}$ & $1,86 \pm 0,11^{\mathrm{c}}$ & $15,51 \pm 0,54^{\mathrm{e}}$ & $5,09 \pm 0,11^{a}$ & $77,55 \pm 0,77^{\mathrm{e}}$ & $10,53 \pm 0,83^{\mathrm{e}}$ \\
\hline \multicolumn{7}{|c|}{ Kedelai Detam-1 } \\
\hline 0 & $6,80 \pm 1,14^{\mathrm{a}}$ & $0,70 \pm 0,05^{a}$ & $6,53 \pm 0,26^{a}$ & $0,66 \pm 0,02^{a}$ & $92,11 \pm 0,30^{a}$ & $3,44 \pm 0,29^{a}$ \\
\hline 10 & $8,16 \pm 2,09^{a}$ & $1,25 \pm 0,06^{D}$ & $10,94 \pm 0,43^{\mathrm{D}}$ & $1,04 \pm 0,07^{\mathrm{ab}}$ & $86,77 \pm 0,41^{\mathrm{D}}$ & $4,79 \pm 0,56^{\mathrm{ao}}$ \\
\hline 15 & $9,74 \pm 0,69^{a}$ & $1,52 \pm 0,10^{\mathrm{C}}$ & $13,09 \pm 0,67^{\mathrm{c}}$ & $1,27 \pm 0,13^{\circ}$ & $84,12 \pm 0,90^{\mathrm{C}}$ & $6,73 \pm 1,07^{\mathrm{DC}}$ \\
\hline 20 & $8,00 \pm 1,30^{a}$ & $1,77 \pm 0,11^{\mathrm{c}}$ & $15,37 \pm 0,67^{\mathrm{a}}$ & $2,45 \pm 0,26^{\mathrm{c}}$ & $80,41 \pm 1,04^{a}$ & $7,85 \pm 0,69^{\mathrm{ca}}$ \\
\hline 25 & $6,04 \pm 0,45^{a}$ & $2,06 \pm 0,07^{a}$ & $17,45 \pm 0,50^{\mathrm{e}}$ & $3,92 \pm 0,14^{a}$ & $76,57 \pm 0,72^{\mathrm{e}}$ & $9,76 \pm 1,08^{a}$ \\
\hline
\end{tabular}

Keterangan: Hurufyang sama pada kolom yang sama berarti tidak berbeda nyata pada $a=0,05$

Hal yang sama terjadi dengan kadar lemak dari beras analog, yaitu kadarny a meningkat dari $0,66 \pm$ $0,02 \%$ (tanpa penambahan tepung kedelai) menjadi $1,14 \pm 0,36-5,09 \pm 0,11 \%$ (penambahan tepung kedelai Grobogan) dan 1,04 $\pm 0,07-3,92 \pm 0,14 \%$ (penambahan tepung kedelai Detam-1). Kandungan lemak beras analog cenderung meningkat disebabkan oleh penambahan kedelai. Penambahan lemak ini dapat berasosiasi negatif pada beberapa kalangan yang ingin menurunkan asupan lemak. Meskipun demikian, sekitar $60 \%$ as am lemak pada kacang kedelai terdiri dari asam lemak tidak jenuh, diantaranya merupakan asam lemak esensial seperti asam linolenat dan linoleat yang dapat memberikan efek fungsional bagi tubuh (Krisnawati, 2017).

Penambahan tepung kedelai juga meningkatkan kadar serat pangan, namun menurunkan kadar karbohidrat (Tabel 4). Menurunnya kadar karbohidrat dan meningkatnya serat pangan dapat berkontribusi terhadap menurunnya indeks glikemik. Menurut Messina (2014), kacang-kacangan, termasuk kedelai, kaya akan serat total dan larut serta pati resisten, yang berkontribusi terhadap indeks glikemik yang rendah. Noviasari et al. (2015) telah membuktikan bahwa penambahan tepung kedelai sebanyak $10 \%$ dapat menghasilkan beras analog dengan nilai indeks glikemik 50 , yang lebih rendah dari nilai indeks glikemik beras analog dengan bahan baku jagung putih dengan nilai indeks glikemik 69. Indeks glikemik yang rendah dapat bermanfaat dalam pencegahan penyakit degeneratif seperti diabetes. Selain itu, serat pangan juga dapat bermanfaat untuk kesehatan usus.

\section{Daya ikat air}

Daya ikat air dapat memengaruhi tekstur nasi dari beras analog. Semakin rendah daya ikat air, maka semakin kering nasi yang dihasilkan setelah ditanak. Daya ikat air beras analog tanpa penambahan tepung kedelai adalah sebesar 4,35 $\pm 0,06 \mathrm{~g}$ air/g sampel (Gambar 1). Penambahan tepung kedelai Grobogan ke dalam formulasi beras analog menurunkan daya ikat air secara nyata $(P<0,05)$ pada rentang $4,18 \pm 0,08-3,26 \pm 0,37 \mathrm{~g}$ air/g sampel. Daya ikat air cenderung menurun dengan semakin tingginya tepung kedelai yang ditambahkan. Hal yang sama ditunjukkan oleh beras analog dengan penambahan tepung kedelai Detam-1 dengan rentang 4,04 $\pm 0,02-2,77 \pm 0,31 \mathrm{~g}$ air $/ \mathrm{g}$ sampel. Perbedaan jenis kedelai yang ditambahkan pada konsentrasi yang sama cenderung memberikan daya ikat air yang relatif sama. Hasil yang diperoleh, dapat disimpulkan bahwa nasi dari beras analog akan menjadi lebih kering seiring dengan meningkatnya tepung kedelai.

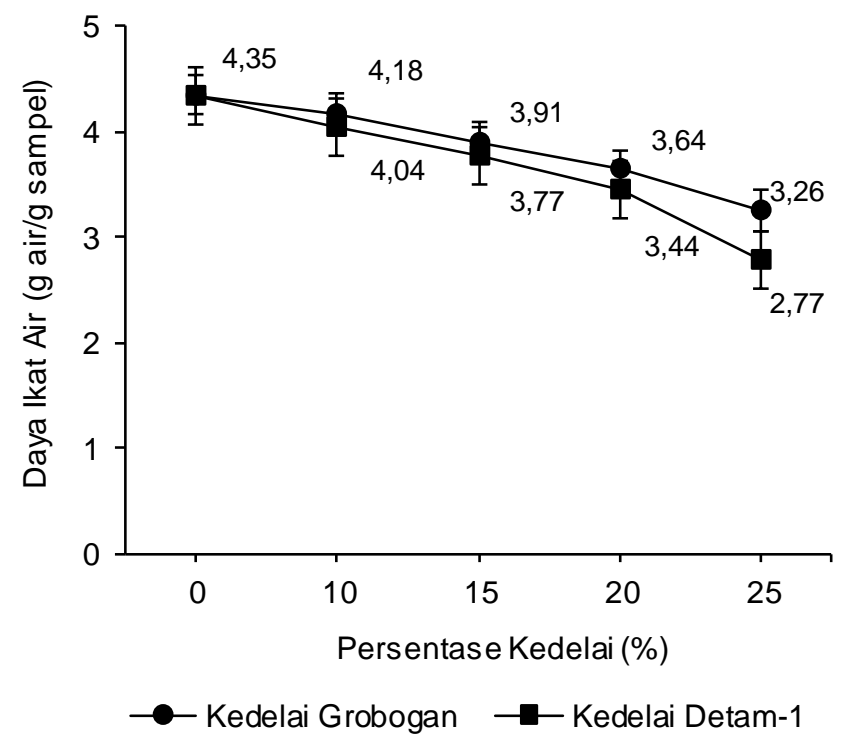

Gambar 1. Daya ikat air beras analog dengan penambahan tepung kedelai varietas Grobogan/kedelai Detam-1

Hasil analisis daya ikat air pada penelitian ini berbeda dengan yang dilaporkan oleh Traynham (2007). Perbedaan ini diperkirakan terjadi karena tepung kedelai yang digunakan dalam penelitian ini 
adalah tepung kedelai utuh tanpa pembuangan lemak, sedangkan yang digunakan Traynham (2007) adalah tepung kedelai bebas lemak dan tepung kedelai rendah lemak. Peningkatan lemak pada beras analog dalam penelitian ini yang seiring dengan bertambahnya persentase kedelai dapat berkontribusi terhadap daya ikat air yang menurun. Adanya lemak dalam tepung yang bersifat hidrofobik dapat menghalangi pengikatan air dan menurunkan nilai daya ikat air (Traynham, 2007). Hal ini didukung oleh Jimoh dan Olatidoye (2009) yang menggunakan tepung kedelai utuh dan membuktikan bahwa kemampuan tepung komposit ubi dan kedelai untuk menyerap air menurun seiring dengan jumlah tepung kedelai yang ditambahkan.

\section{Kekerasan dan kepaduan}

Mutu tekstur dari beras analog yang telah ditanak ditunjukkan oleh kekerasan (hardness) dan kepaduan (cohesiveness). Hasil TPA menunjukkan bahwa kekerasan dan kepaduan nasi analog menurun secara nyata $(P<0,05)$ dengan bertambahnya kedelai, baik yang ditambahkan tepung kedelai Grobogan maupun Detam-1 (Gambar 2 dan Gambar 3). Hasil ini mengindikasikan bahwa tekstur beras analog menjadi lebih lunak dan kurang kompak dengan penambahan tepung kedelai. Hal ini dapat memengaruhi sensasi pada saat memakan nasi dari beras analog. Semakin lunak dan mudah hancur, maka akan semakin terkesan seperti memakan bubur.

Das et al. (2008) juga melaporkan bahwa penambahan pasta kedelai penuh lemak pada produk nugget cenderung menurunkan nilai kekerasan (hardness), kekenyalan (springiness), dan daya kunyah (chewiness) secara nyata. Penambahan tepung kedelai juga menurunkan kekerasan dari adonan roti setengah matang, namun tidak memengaruhi nilai kepaduan (Serventi et al., 2011). Hal ini dapat disebabkan oleh kandungan protein yang tinggi sehingga menyebabkan terbentuknya pori pada struktur pangan saat diolah pada suhu tinggi, seperti proses ekstrusi panas. Selain itu, Shevkani dan Singh (2014) menyatakan bahwa penambahan isolat protein dari kacang merah, kapri dan amaranth pada muffin bebas gluten dapat meningkatkan viskoelastisitas adonan muffin, sehingga menghasilkan muffin yang lebih mengembang dan teraerasi. Pada proses produksi beras analog, adonan yang telah dicampur diolah dengan teknologi ekstrusi panas. Proses ekstrusi panas melibatkan perlakuan panas dan tekanan secara bersamaan yang dapat menyebabkan perubahan pada ekstrudat, seperti gelatinisasi pati dan denaturasi protein ( $\mathrm{Yu}$ et al., 2012). Saat proses ekstrusi, protein terdenaturasi dan kemudian membentuk agregat protein yang distabilkan oleh interaksi kovalen dan non-kovalen sehingga membentuk struktur anisotropik (Pietsch et al., 2019). Pada saat ekstrudat keluar dari lubang (die), terjadi penurunan tekanan secara tiba-tiba dan menyebabkan evaporasi air sehingga membentuk struktur mikropori (Budijanto dan Juliana, 2015). Proses ini diduga dapat menyebabkan struktur beras analog mengembang dan teraerasi, sehingga menurunkan kekerasan dan kepaduan dari beras analog yang dihasilkan. Selain itu, menurunnya nilai kekerasan dapat disebabkan dari gangguan langsung pada jaringan pati yang disebabkan oleh protein kedelai, sehingga menurunkan kekakuan jaringan pati (Siegwein et al., 2011).

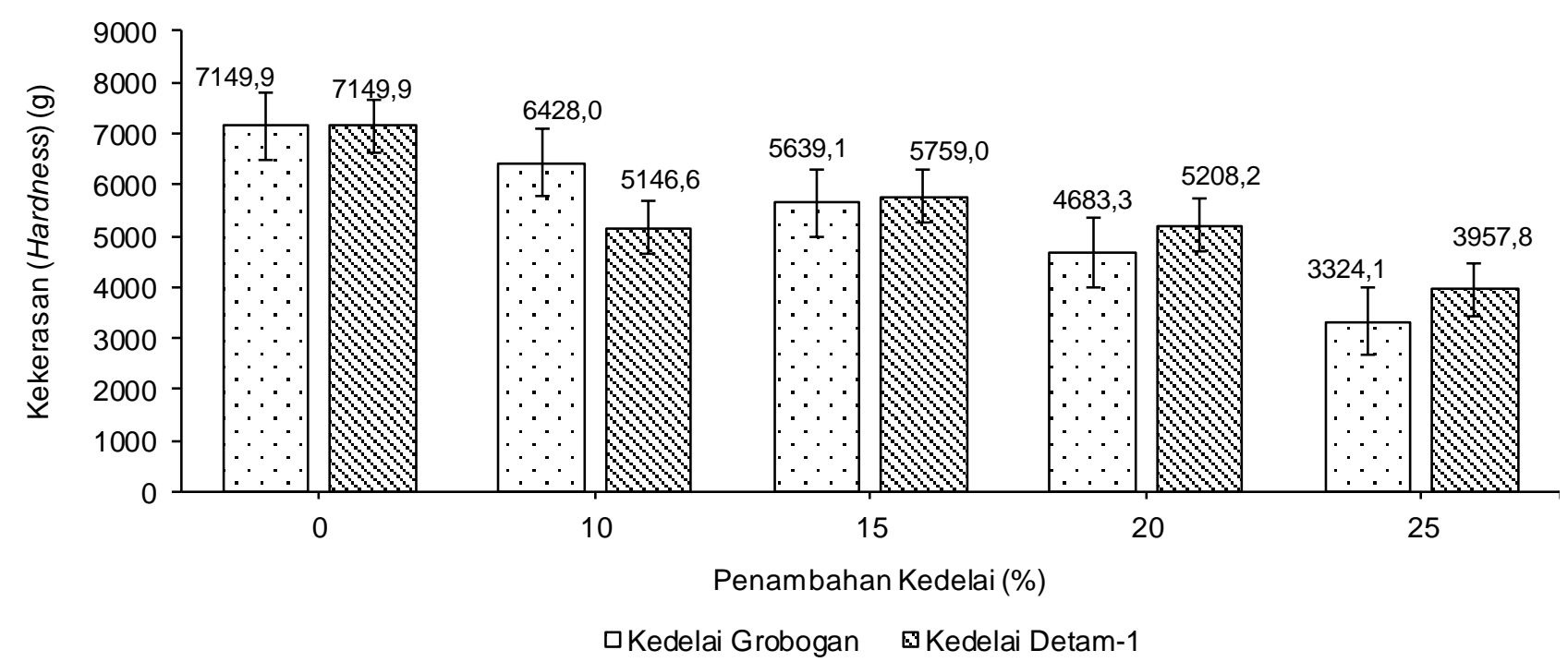

Gambar 2. Kekerasan (hardness) beras analog dengan penambahan tepung kedelai varietas Grobogan dan Detam-1 


\section{Mutu sensori}

Uji sensori dilakukan pada sampel beras analog dengan penambahan tepung kedelai hingga $25 \%$ (Tabel 5). Hasil analisis sensori terhadap atribut tekstur kelengketan, kekerasan, dan kepaduan massa menunjukkan perbedaan yang tidak nyata $(P>0,05)$ untuk sampel dengan penambahan tepung kedelai hingga $25 \%$. Hasil uji sensori ini berbeda dengan hasil analisis tekstur dengan texture analyzer, yaitu menunjukkan perbedaan yang nyata pada atribut kekerasan dan kepaduan dengan penambahan tepung kedelai. Penambahan tepung kedelai tidak memengaruhi persepsi panelis secara nyata pada atribut tekstur kekerasan dan kepaduan pada penambahan tepung kedelai hingga $25 \%$, walaupun pengujian tekstur dengan instrumen menunjukkan perbedaan yang signifikan. Hal ini menunjukkan bahwa panelis tidak dapat membedakan penurunan kekerasan dan kepaduan beras yang dapat dideteksi oleh alat, sehingga penambahan tepung kedelai hingga 25\% tidak memengaruhi kekerasan dan kepaduan secara sensoris.

Panelis dapat merasakan perbedaan yang nyata pada atribut kelembapan, yaitu pada taraf penambahan kedelai 20 dan $25 \%$, yaitu panelis menilai sampel yang lebih kering dibandingkan dengan sampel yang lain (Tabel 5). Hasil ini menunjukkan bahwa daya ikat air yang menurun memengaruhi persepsi tekstur oleh panelis. Daya ikat air yang rendah dan nilai kelembapan nasi yang cenderung lebih rendah pada penambahan kedelai di atas $20 \%$ menunjukkan bahwa air tidak masuk ke dalam matriks beras analog ketika dimasak dan tidak berinteraksi dan berikatan dengan komponen lain seperti protein dan karbohidrat, sehingga menghasilkan tekstur yang lebih kering. Keringnya nasi dari beras analog ini dapat membuat konsumen tidak menikmati nasi beras analog dengan penambahan tepung kedelai di atas $20 \%$.

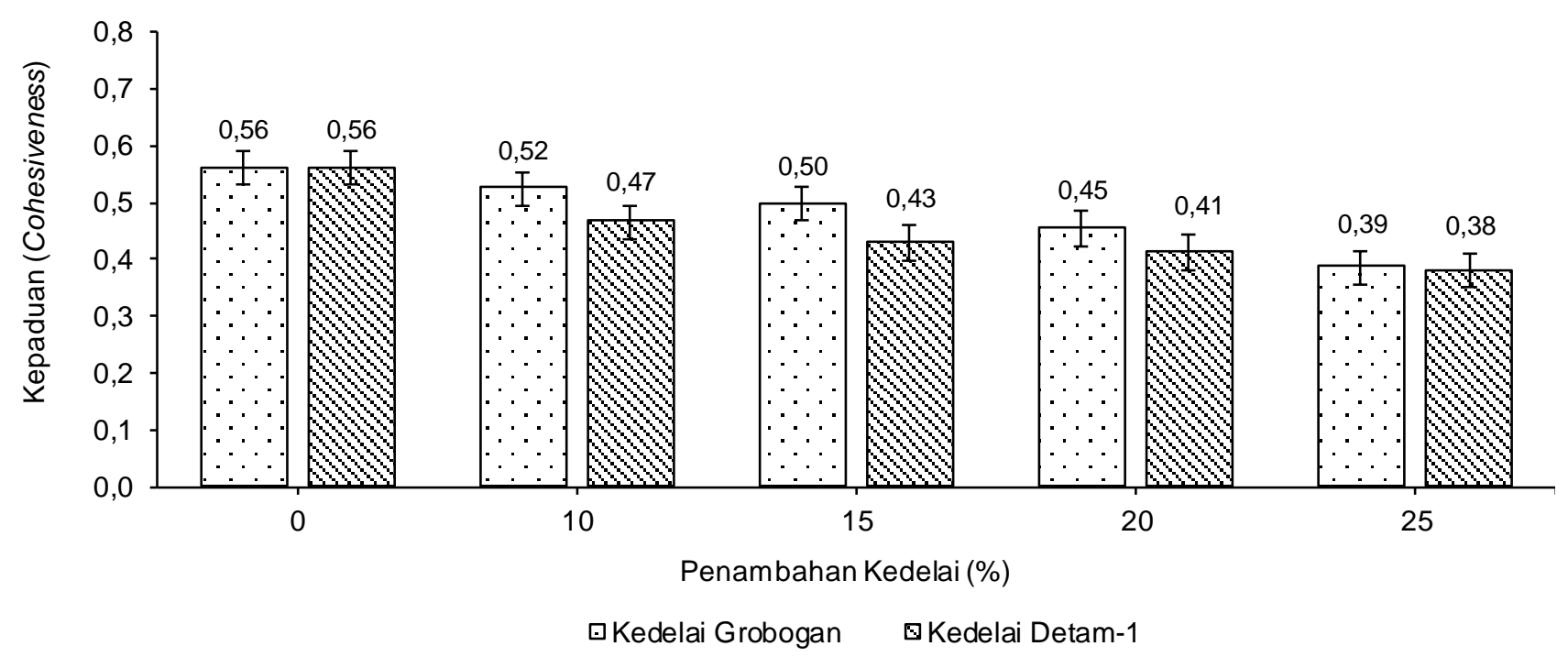

Gambar 3. Kepaduan (cohesiveness) beras analog dengan penambahan tepung kedelai varietas Grobogan dan Detam-1

Tabel 5. Mutu sensori beras analog jagung dengan penambahan tepung kedelai varietas Grobogan/Detam-1

\begin{tabular}{ccccc}
\hline Persentase Kedelai (\%) & Kelengketan & Kekerasan & Kepaduan Massa & Kelembapan \\
\hline Kedelai Grobogan & & & & \\
\hline 0 & $5,8 \pm 3,3^{\mathrm{a}}$ & $3,0 \pm 1,1^{\mathrm{a}}$ & $5,8 \pm 1,9^{\mathrm{a}}$ & $3,9 \pm 0,6^{\mathrm{a}}$ \\
10 & $4,1 \pm 2,7^{\mathrm{a}}$ & $2,4 \pm 1,6^{\mathrm{a}}$ & $6,0 \pm 2,3^{\mathrm{a}}$ & $4,2 \pm 0,6^{\mathrm{a}}$ \\
15 & $6,1 \pm 3,3^{\mathrm{a}}$ & $1,8 \pm 0,9^{\mathrm{a}}$ & $6,7 \pm 1,7^{\mathrm{a}}$ & $4,7 \pm 1,9^{\mathrm{a}}$ \\
20 & $5,8 \pm 2,7^{\mathrm{a}}$ & $1,9 \pm 1,0^{\mathrm{a}}$ & $5,6 \pm 2,8^{\mathrm{a}}$ & $3,5 \pm 0,7^{\mathrm{a}}$ \\
25 & $4,6 \pm 2,4^{\mathrm{a}}$ & $1,7 \pm 1,2^{\mathrm{a}}$ & $5,9 \pm 2,6^{\mathrm{a}}$ & $3,8 \pm 0,6^{\mathrm{D}}$ \\
\hline Kedelai Detam-1 & & & & \\
\hline 0 & $5,8 \pm 3,3^{\mathrm{a}}$ & $3,0 \pm 1,1^{\mathrm{a}}$ & $5,8 \pm 1,9^{\mathrm{a}}$ & $3,9 \pm 0,6^{\mathrm{a}}$ \\
10 & $6,1 \pm 3,8^{\mathrm{a}}$ & $2,6 \pm 1,4^{\mathrm{a}}$ & $6,7 \pm 1,5^{\mathrm{a}}$ & $4,3 \pm 1,0^{\mathrm{a}}$ \\
15 & $5,8 \pm 3,5^{\mathrm{a}}$ & $2,1 \pm 1,1^{\mathrm{a}}$ & $7,2 \pm 2,1^{\mathrm{a}}$ & $4,4 \pm 0,6^{\mathrm{a}}$ \\
20 & $4,0 \pm 1,7^{\mathrm{a}}$ & $2,6 \pm 1,4^{\mathrm{a}}$ & $5,5 \pm 2,0^{\mathrm{a}}$ & $3,3 \pm 0,6^{\mathrm{a}}$ \\
25 & $4,8 \pm 3,0^{\mathrm{a}}$ & $2,4 \pm 1,5^{\mathrm{a}}$ & $5,6 \pm 1,6^{\mathrm{a}}$ & $3,6 \pm 0,7^{\mathrm{a}}$ \\
\hline
\end{tabular}

Keterangan: Huruf yang sama pada kolom yang sama berarti tidak berbeda nyata pada $a=0,05$ 


\section{KESIMPULAN}

Penambahan tepung kedelai varietas Grobogan atau Detam-1 berhasil meningkatkan kadar protein sehingga dapat diklaim sebagai beras analog tinggi protein dengan penambahan tepung kedelai Grobogan sebanyak $20 \%$ dan tepung kedelai Detam-1 sebanyak $15 \%$. Penambahan tepung kedelai juga meningkatkan kadar lemak dan serat pangan serta menurunkan kadar karbohidratnya. Meskipun peningkatan tepung kedelai menurunkan nilai kekerasan (hardness) dan kepaduan (cohesiveness) dari beras analog yang dihasilkan, perubahan tersebut tidak dapat dirasakan oleh panelis. Penurunan daya ikat air yang disebabkan oleh bertambahnya tepung kedelai tidak dapat dirasakan oleh panelis hingga penambahan tepung kedelai sebanyak $20 \%$. Penelitian selanjutnya diperlukan untuk mengatasi masalah daya ikat air dan kelembapan produk beras analog yang masih rendah. Penggunaan tepung kedelai yang dihilangkan lemaknya (defatted soybean flour) dapat menjadi alternatif untuk mengatasi masalah tersebut.

\section{UCAPAN TERIMAKASIH}

Ucapan terima kasih diucapkan kepada Kementerian Riset, Teknologi, dan Perguruan Tinggi Republik Indonesia melalui program pendanaan Penelitian Unggulan Perguruan Tinggi tahun 2017.

\section{DAFTAR PUSTAKA}

Adicandra RM, Estiasih T. 2016. Beras analog dari ubi kelapa putih (Discorea alata L.): Kajian pustaka. J Pangan Agroind 4: 383-390.

[AOAC] Association of Official Analytical Chemistry. 2005. Official Method of Analysis. AOAC Inc, Washington DC (US).

[Balitkabi] Balai Penelitian Tanaman Aneka Kacang dan Umbi. 2016. Deskripsi Varietas Unggul Aneka Kacang dan Umbi. KD-66-KD-68. Badan Penelitian dan Pengembangan Pertanian, Malang.

[BPOM] Badan Pengawas Obat dan Makanan. 2016. Peraturan Kepala Badan Pengawas Obat dan Makanan Tentang Pengawasan Klaim pada Label dan Iklan Pangan Olahan. Jakarta.

Budijanto S, Yuliyanti. 2012. Studi persiapan tepung sorgum (Sorghum bicolor L. Moench) dan aplikasinya pada pembuatan beras analog. J Teknol Pertanian 13: 177-186.

Budijanto S, Yuliana ND. 2015. Development of rice analog as a food diversification vehicle in
Indonesia. J Develop in Sust Agric 10: 7-14. DOI: $10.11178 /$ jdsa.10.7.

Caesarina I, Estiasih T. 2016. Beras analog dari Garut (Maranta arundinaceae): Kajian Pustaka. J Pangan Agroind 4: 498-504.

Das AK, Anjaneyulu ASR, Gadekar YP, Singh RP, Pragati H. 2008. Effect of full-fat soy paste and textured soy granules on quality and shelf-life of goat meat nuggets in frozen storage. Meat Sci 80: 607-614. DOI: 10.1016/j.meatsci.2008.02. 011.

Ginting E, Yulifianti R, Mulyana HI, Tarmizi. 2015. Varietas unggul kedelai hitam sebagai bahan baku kecap. Prosiding Seminar Agroindustri dan Lokakarya Nasional FKPT-TPI, Program Studi TIP-UTM, September 2015.

Herawati H, Kusnandar F, Adawiyah DR, Budijanto S. 2013. Teknologi proses pembentukan butiran beras artifisial instan dengan metode ekstrusi. J Pangan 22: 317-327.

Hiday at M, Kurnia D, Sujatno M, Sutadipura N, Setiawan. 2010. Perbandingan kandungan makronutrisi dan isoflavon dari kedelai Detam-1 dan Wilis serta potensinya dalam menurunkan berat badan. Bionatura-J IImu-IImu Hayati Fisik 12: $5-13$.

Huang X, Yi T, Yang F, Xu C, Li G, Hu W, Bi D, Pan S. 2014. Effects of sodium tripolyphosphate, microbial transglutaminase and enzyme-hydrolyzed soy protein fraction on the quality of cooked pork batter by response surface methodology. Adv J Food Sci Tech 6: 1228-1240. DOI: 10.19026/ajfst.6.189.

Jimoh KO, Olatidoye OP. 2009. Evaluation of physicochemical and rheological characteristics of soybean fortified yam flour. J Applied Biosci 13: 703-706.

Julianti E, Rusmarilin H, Ridwansyah, Yusraini E. 2015. Effect of soybean flour on physicochemical, functional, and rheological properties of composit flour from rice, sweet potato, and potato. Trop Life Sci Res 27: 133-138. DOI: 10. 21315/tlsr2016.27.3.18.

Krisnawati A. 2017. Kedelai sebagai sumber pangan fungsional. Iptek Tanaman Pangan 12: 57-65.

Kurniawati M, Budijanto S, Yuliana ND. 2016. Karakterisasi dan indeks glikemik beras analog berbahan dasar jagung. J Gizi Pangan 11: 169147.

Kwak HS, Jeong Y, Kim M. 2015. Influence of rice varieties on sensory profile and consumer acceptance for frozen-cooked rice. Emir J Food Agric 27: 793-800. DOI: 10.9755/ejfa.2015-04139. 
Lee JH, Cho AR, Hong JY, Park DJ, Lim ST. 2012. Physical properties of wheat flour composites dry-coated with microparticulated soybean hulls and rice flour and their use for low-fat doughnut preparation. J Cereal Sci 56: 636-643. DOI: 10. 1016/j.jcs.2012.08.011.

Li H, Prakash S, Nicholson TM, Fitzgerald MA, Gilbert RG. 2016. The importance of amylose and amylopectin fine structure for textural properties of cooked rice grains. Food Chem 196: 702-711. DOI: 10.1016/j.foodchem.2015.09.1 12.

Li JY, Yeh Al, Fan KL. 2007. Gelation characteristics and morphology of corn starch/soy protein concentrate composites during heating. J Food Eng 78: 1240-1247. DOI: 10.1016/j.jfoodeng. 2005. 12.043.

McCleary BV, Sloane N, Draga A, Lazewska I. 2013. Measurement of total dietary fiber using aoac method 2009.01 (AACC international approved method 32-45.01): evaluation and updates. Cereal Chem 90: 396-414. DOI: 10.1094/ CCHEM-10-12-0135-FI.

Messina V. 2014. Nutritional and health benefits of dried beans. Am J Clin Nutr 100: 437S-442S. DOI: 10.3945/ajcn.113.071472.

Mishra A, Mishra HN, Rao PS. 2012. Preparation of rice analogues using extrusion technology. Int $\mathrm{J}$ Food Sci Tech 47: 1789-1797. DOI: 10.1111/j.1 365-2621.2012.03035.x.

Noviasari S, Kusnandar F, Budijanto S. 2013. Pengembangan beras analog dengan memanfaat kan jagung putih. J Teknol Industri Pangan 24: 195-201. DOI: 10.6066/jtip.2013.24.2.194.

Noviasari S, Kusnandar F, Setiyono A, Budijanto S. 2015. Beras analog sebagai pangan fungsional dengan indeks glikemik rendah. J Gizi Pangan 10: 225-232.

Nurrahman. 2015. Evaluasi komposisi zat gizi dan senyawa antioksidan kedelai hitam dan kedelai kuning. J Aplikasi Teknologi Pangan 4: 89-93. DOI: 10.17728/jatp.v4i3.133.

Otegbayo B O, Adebiyi OM, Bolaji OA, Olunlade BA. 2018. Effect of soy enrichment on bread quality. Int Food Res J 25: 1120-1125.

Pietsch VL, Bühler JM, Karbstein HP, Emin MA. 2019. High moisture extrusion of soy protein concentrate: Influence of thermomechanical treatment on protein-protein interactions and rheological properties. J Food Eng 251: 11-18. DOI: 10.1016/j.jfoodeng.2019.01.001.

Putseys JA, Derde LJ, Lamberts L, Ostman E, Björck IM, Delcour JA. 2010. Functionality of short chain amylose-lipid complexes in starchwater systems and their impact on in-vitro starch degradation. J Agric Food Chem 58: 1939-1945. DOI: 10.1021/jf903523h.

Shevkani K, Singh N. 2014. Influence of kidney bean, field pea and amaranth protein isolates on the characteristics of starch-based glutenfree muffins. Int J Food Sci Tech 49: 2237 2244. DOI: $10.1111 /$ ijfs. 12537.

Serventi L, Sachleben J, Vodovotz Y. 2011. Soy addition improves the texture of microwavable par-baked pocket-type flat doughs. J Therm Anal Calorim 106: 117-121. DOI: 10.1007/s10 973-011-1415-y.

Siegwein AM, Vodovotz Y, Fisher EL. 2011. Concentration of soy protein isolate affects starchbased confections' texture, sensory, and storage properties. J Food Sci 76: 422-428. DOI: 10.1111/j.1750-3841.2011.02241.x.

Sitakalin C, Meullenet JFC. 2000. Prediction of cooked rice texture using extrusion and compression tests in conjunction with spectral stress strain analysis. Cereal Chem 77: 501506. DOI: 10.1094/CCHEM.2000.77.4.501.

Traynham TL, Myers DJ, Carriquiry AL, Johnson LA. 2007. Evaluation of water-holding capacity for wheat-soy flour blends. J Am Oil Chem Soc 84: 151-155. DOI: 10.1007/s11746-006-1018-0.

Triandita N, Zakaria FR, Prangdimurti E, Putri NE. 2016. Perbaikan status antioksidan penderita diabetes tipe 2 dengan tahu kedelai hitam kaya serat. J Teknol Industri Pangan 27: 123-130. DOI: 10.6066/jtip.2016.27.2.123.

Wahjuningsih SB, Marsono Y, Praseptiangga D, Hary anto B. 2016. Resistant starch content and glycaemic index of sago (Metroxylon spp.) starch and red bean (Phaseolus vulgaris) based analogue rice. Pakistan J Nutr 15: 667-672. DOI: 10.3923/pjn.2016.667.672.

Wolfe RR. 2012. The role of dietary protein in optimizing muscle mass, function and health outcomes in older individuals. British J Nutr 108: S88-S93. DOI: 10.1017/S0007114512002590.

Yu L, Ramaswamy HS, Boye J. 2012. Twin-screw extrusion of corn flour and soy protein isolate (SPI) blends: A response surface analysis. Food Bioproc Technol 5: 485-497. DOI: 10.10 07/s11947-009-0294-8.

Yudanti YR, Waluyo S, Tamrin. 2015. Pembuatan beras analog berbahan dasar tepung pisang (Musa paradisiaca). J Teknik Pertanian Lampung 4: 117-126.

Yuwono SS, Zulfiah AA. 2015. Formulasi beras analog berbasis tepung mocaf dan maizena dengan penambahan CMC dan tepung ampas tahu. J Pangan Agroind 3: 1465-1472. 